CZASOPISMO INŻYNIERII LĄDOWEJ, ŚRODOWISKA I ARCHITEKTURY JOURNAL OF CIVIL ENGINEERING, ENVIRONMENT AND ARCHITECTURE

JCEEA, t. XXXIII, z. 63 (2/II/16), kwiecień-czerwiec 2016, s. 359-369

Kamil Błażej POCHWAT ${ }^{1}$

Daniel SEY Ś

\title{
ANALIZA HYDRAULICZNA FUNKCJONOWANIA ZBIORNIKA RETENCYJNEGO WYPOSAŻONEGO W INSTALACJE OBIEKTÓW RETENCYJNYCH
}

\begin{abstract}
Instalacja obiektów retencyjnych jest innowacyjnym rozwiązaniem umożliwiającym przekształcenie układu hydraulicznego dowolnego zbiornika jednokomorowego w układ wielokomorowy. Główną ideą wynalazku jest wprowadzenie do wnętrza zbiornika przewodu połączonego hydraulicznie na wlocie i wylocie, co pozwala na zmniejszenie czasu przepływu ścieków przez obiekt, co w konsekwencji pozwala na zmniejszenie jego niezbędnej pojemności retencyjnej. W publikacji scharakteryzowano przedstawione rozwiązanie oraz zawarto wyniki analiz hydraulicznego funkcjonowania klasycznego zbiornika kanalizacyjnego ścieków deszczowych lub ogólnospławnych wyposażonego w przedmiotowe innowacyjne rozwiązanie, które pozwala na zmaksymalizowanie efektywności kubaturowej dowolnego zbiornika retencyjnego. Szczególną uwagę zwrócono na warunki hydrauliczne w zakresie napełnienia ściekami poszczególnych elementów zbiornika tj. kanału wiodącego i komory akumulacyjnej. Badania oparto na analizie poszczególnych faz funkcjonowania kanalizacyjnego zbiornika w systemie kanalizacji deszczowej zawierającego przedmiotową instalację. Badania przeprowadzono w fazach od wystąpienia opadu i rozpoczęcia dopływu strumienia objętości ścieków do zbiornika po zakończenie opadu i całkowite opróżnienie obiektu retencyjnego.
\end{abstract}

Słowa kluczowe: zbiorniki retencyjne, innowacje, efekt kubaturowy, systemy kanalizacyjne, systemy odwodnieniowe, kanalizacja deszczowa, kanalizacja ogólnospławna, retencja zbiornikowa, model hydrauliczny.

\section{Wprowadzenie}

Coraz powszechniej wykorzystywanym elementem w nowoczesnych zrównoważonych systemach odwodnień są zbiorniki retencyjne [1-3]. Stosowanie tych obiektów bardzo często wynika z konieczności zmniejszenia strumienia objętości przepływających ścieków w celu umożliwienia prawidłowego funk-

\footnotetext{
${ }^{1}$ Autor do korespondencji / corresponding author: Kamil Błażej Pochwat, Politechnika Rzeszowska, Zakład Infrastruktury i Ekorozwoju, al. Powstańców Warszawy 6, 35-959 Rzeszów; tel.: 177432409,kp@prz.edu.pl.

2 Daniel Słyś, Politechnika Rzeszowska, Zakład Infrastruktury i Ekorozwoju, al. Powstańców Warszawy 6, 35-959 Rzeszów; tel.: 178651784; daniels@prz.edu.pl
} 
cjonowania przeciążonego hydraulicznie systemu [4-5]. Istnieje zazwyczaj kilka alternatywnych możliwości rozwiązania tego problemu, a wybór najkorzystniejszej z nich jest możliwy w oparciu o analizę różnych kryteriów [6], z których najważniejsze to czynniki techniczne i ekonomiczne [7-11].

Ze względu na znaczne wymiary i skomplikowaną konstrukcję obiekty retencyjne wymagają wysokich nakładów inwestycyjnych ponoszonych na ich budowę [12]. Zatem, wskazanym jest wykorzystywanie takich rozwiązań, które umożliwią minimalizację ich niezbędnej pojemności $V_{u}$, a w konsekwencji nakładów inwestycyjnych, przy zapewnieniu założonego poziomu bezpieczeństwa działania systemów kanalizacyjnych [13].

W publikacji przedstawiono analizę hydrauliczną funkcjonowania jednego z innowacyjnych rozwiązań obiektów retencyjnych, które pozwala na zmniejszenie niezbędnej pojemności retencyjnej zbiornika poprzez zwiększenie jego efektywności hydraulicznej.

\section{Cel analizy}

Celem badań jest przeprowadzenie analizy hydraulicznej funkcjonowania zbiornika retencyjnego posiadającego zintegrowany system pn. instalacja obiektów retencyjnych, który pozwala na zwiększenie efektywności kubaturowej obiektu.

W rozważaniach wykorzystano najpowszechniej stosowany w systemach kanalizacyjnych zbiornik retencyjny działający w układzie przepływowym o jednej komorze akumulacyjnej. Zbiornik ten został zmodernizowany poprzez zaopatrzenie go w układ zwiększający efektywność hydrauliczną. Zrealizowane zostało to przez zastosowanie innowacyjnego rozwiązania pn. Instalacja zbiorników retencyjnych, która została zgłoszona do ochrony patentowej na terenie Unii Europejskiej [14].

Badany zbiornik został przedstawiony i opisany na schemacie aksonometrycznym (rys. 1).

\section{Opis rozwiązania}

Instalacja obiektów retencyjnych jest innowacyjnym rozwiązaniem, w który można wyposażyć dowolny obiekt retencyjny. Szczególnym atutem prezentowanego rozwiązania jest możliwość jego wykorzystania, zarówno w obiektach nowoprojektowanych, jak i istniejących zbiornikach przepływowych zwiększając jednocześnie ich efektywność hydrauliczną.

Przedmiotowe rozwiązanie stanowi połączenie kanału dopływowego obiektu retencyjnego z odpływowym poprzez kanał przelewowy. Najistotniejszym elementem rozwiązania jest przelew przewidziany w górnej części kanału przelewowego, który umożliwia odprowadzenie do komory akumulacyjnej obiektu nadwyżki objętości ścieków. 


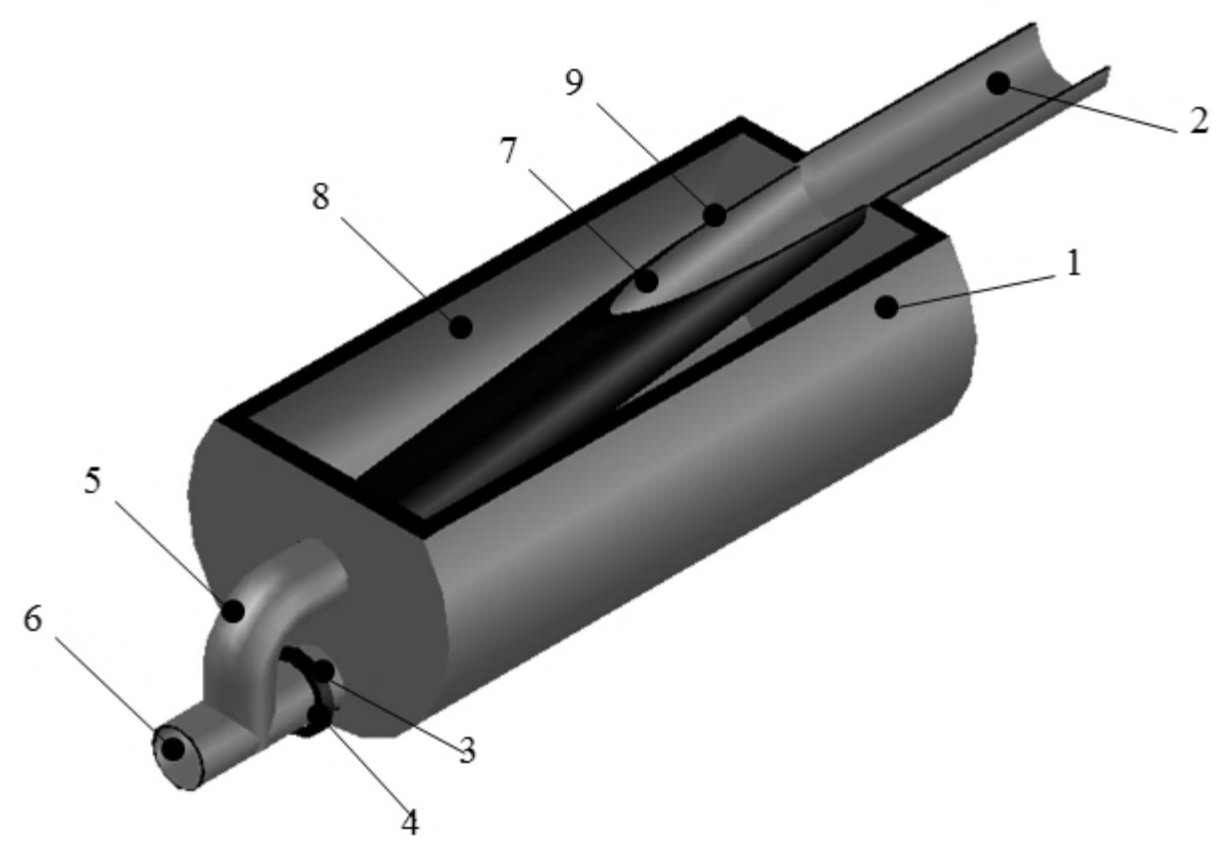

Rys. 1. Wizualizacja przekroju zbiornika rurowego zawierającego instalację minimalizującą niezbędna pojemność retencyjną: 1 - zbiornik retencyjny, 2-kanał dopływowy, 3 - kanał odpływowy ze zbiornika, 4 - zawór klapowy, 5 - kanał wiodący, 6 - kanał odprowadzający ścieki do sieci, 7 - kanał przelewowy, 8 - przestrzeń akumulacyjna zbiornika, 9 - przelew

Fig. 1. Visualization of cross-section of undeground tank containing installation which minimizes the required retention volume: 1 - underground tank, 2 - inflow channel, 3 - first outflow channel, 4 - check valve, 5 - main channel, 6 - second outflow channel, 7 - overflow channel, 8 - retention volume, 9 - overflow

Dopływ ścieków do zbiornika jest realizowany za pomocą kanału dopływowego (2), natomiast odpływ ścieków z przestrzeni akumulacyjnej odbywa się przez kanał odpływowy (3) z zamontowanym na nim zaworem zwrotnym (4).

Główną ideą funkcjonowania przedmiotowej instalacji jest rozdział strugi ścieków na kanały (3) i (5), która ulega połączeniu w kanale odprowadzającym (6).

We wnętrzu komory akumulacyjnej (8) zbiornika znajduje się kanał przelewowy (7), który połączony jest hydraulicznie z kanałem dopływowym (2) i odpływowym (3).

Wstępna analiza przedstawionego rozwiązania pozwoliła stwierdzić, że przedmiotowe rozwiązanie w porównaniu do klasycznego zbiornika jednokomorowego pozwala na zwiększenie efektywności hydraulicznej zbiornika i zminimalizowanie jego niezbędnej pojemności retencyjnej. Na rysunku 2 przedstawiono ideę działania zbiornika wyposażonego w przedmiotową instalację na tle rozwiązania zbiornika jednokomorowego. 

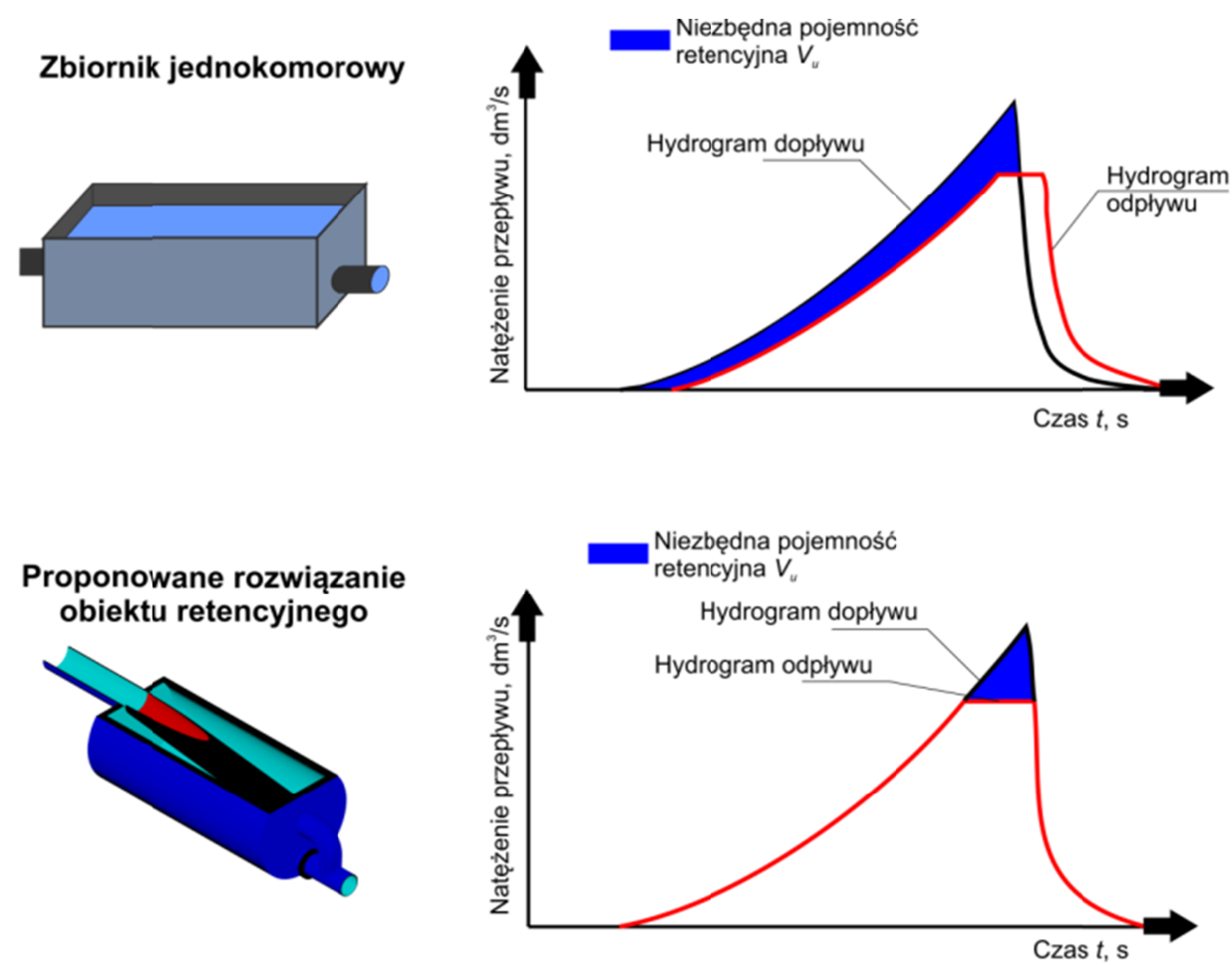

Rys. 2. Idea działania zbiornika retencyjnego wyposażonego w rozwiązanie pn. instalacja obiektów retencyjnych na tle zbiornika jednokomorowego

Fig. 2. The idea of function of the reservoir which contain a solution called Installation of retention facilities for single-chamber tank

\section{Fazy funkcjonowania zbiornika $z$ instalacją obiektów retencyjnych}

W badaniach wykonano analizę hydrauliczną działania zbiornika wyposażonego w Instalacje obiektów retencyjnych w poszczególnych fazach jego napełniania podczas wystąpienia opadu. Schematyczny przekrój badanego zbiornika zobrazowano na rysunku 3, na którym pokazano również schemat przepływów ścieków. 


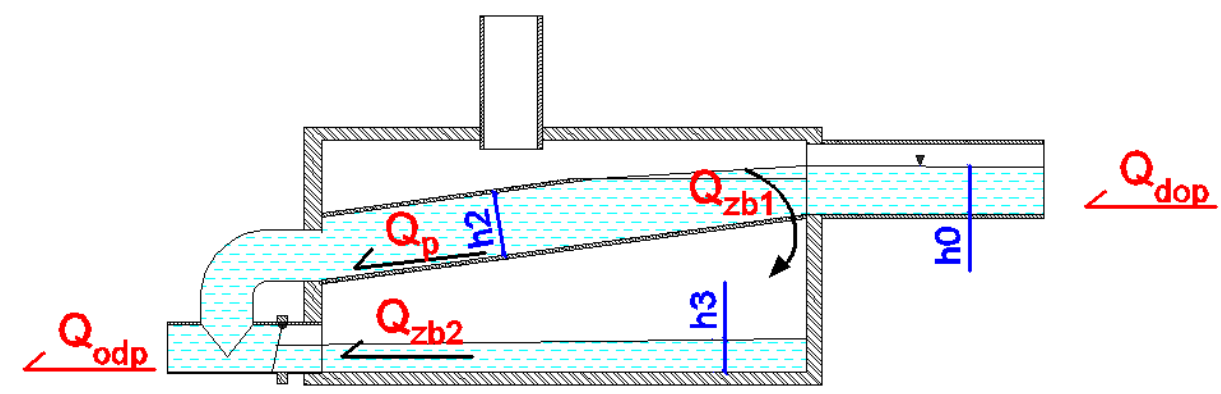

Rys. 3. Przekrój podłużny zbiornika retencyjnego o wysokosprawnym układzie hydraulicznym: $h_{0}$ - napełnienie ścieków w kanale dopływowym, $h_{2}$ - napełnienie ścieków w kanale przelewowym, $\mathrm{h}_{3}-$ napełnienie ścieków w komorze akumulacyjnej zbiornika, $Q_{d o p}$ - strumień objętości ścieków dopływających do zbiornika, $Q_{o d p}-$ strumień objętości ścieków odpływających ze zbiornika, $Q_{p}$ - przepływ ścieków w kanale przelewowy, $Q_{z b 1}$ - odpływ ścieków z kanału przelewowego, $Q_{z b 2}$ - odpływ ścieków z komory akumulacyjnej

Fig. 3. Cross-section of underground tank with hihg effiency hydraulic system: $h_{0}$ - filling of sewage in inflow channel, $h_{2}$ - filling of sewage in overflow channel, $\mathrm{h}_{3}$ - filling of sewage in retention volume, $Q_{d o p}-$ inflow sewage to the tank, $Q_{o d p}$ - outflow sewage, $Q_{p}$ - flow of sewage in overflow channel, $Q_{z b 1}$ - outflow sewage from overflow channel, $Q_{z b 2}$ - outflow of sewage from retention volume

\section{Faza I}

Pierwsza faza funkcjonowania zbiornika wyposażonego w Instalacje obiektów retencyjnych (rys. 4) ma miejsce przed wystąpieniem opadu. W tym czasie dopływ ścieków do zbiornika $Q A$ jest równy 0, a zawór zwrotny (4) jest zamknięty.

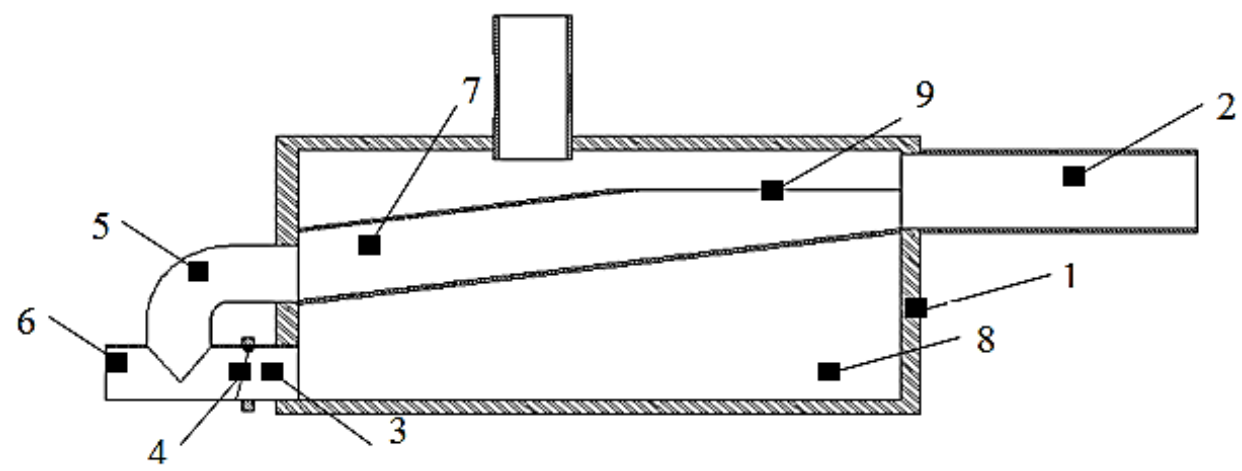

Rys. 4. Faza I funkcjonowania zbiornika

Fig. 4. Phase I of functioning of underground tank

- Warunki brzegowe w zakresie napełnienia: $h_{0.1}=0, h_{2.1}=0, h_{3.1}=0$.

- Warunki brzegowe ze względu na przepływy: $Q_{d o p .1}=0, Q_{o d p .1}=0, Q_{p .1}=0$, $Q_{z b 1.1}=0, Q_{z b 2.1}=0$. 


\section{Faza II}

Kolejna faza funkcjonowania obiektu występuje w początkowym okresie dopływu ścieków opadowych. Doprowadzone do zbiornika ścieki tranısportowane są kanałem przelewowym (9) do kanału wiodącego (5) oraz dalej do wspólnego kanału odpływowego (6). W tym czasie zawór klapowy (4) jest zamknięty, co chroni przed przepływem zwrotnym ścieków do komory akumulacyjnej (8).

Ominięcie komory akumulacyjnej (8) z trasy przepływu ścieków przez zbiornik pozwala na skrócenie czasu przepływu ścieków przez zbiornik, dzięki czemu odpływają niemal natychmiastowo (rys. 5).

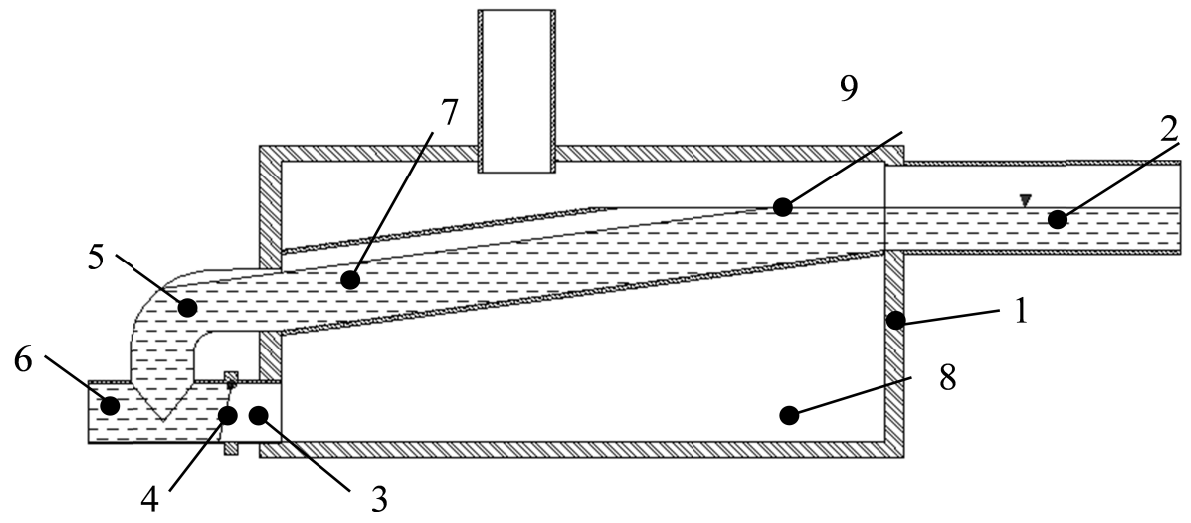

Rys. 5. Faza II funkcjonowania zbiornika

Fig. 5. Phase II of functioning of underground tank

- Warunki brzegowe w zakresie napełnienia: $h_{0.2}>0, h_{2.2}>0, h_{3.2}=0$.

- Warunki brzegowe ze względu na przepływy: $Q_{d o p .2}>0, Q_{o d p .2}>0, Q_{p .2}>0$, $Q_{z b 1.2}=0, Q_{z b 2.2}=0$.

\section{Faza III}

W fazie III (rys. 6) strumień objętości ścieków $Q A$, który doprowadzany jest kanałem przelewowym (7) do kanału wiodącego (5), przewyższa swoją wartością przepustowość kanału odpływowego (6).

Powstała w ten sposób nadwyżka objętości ścieków w wyniku spiętrzenia się w kanale przelewowym (7) zostaje poddana akumulacji w komorze: (8).

Utrzymanie w pozycji zamkniętej zaworu klapowego (4) zapewnia różnica poziomów pomiędzy zwierciadłem ścieków w kanale transportującym (7) a poziomem zwierciadła ścieków w komorze 8 . 


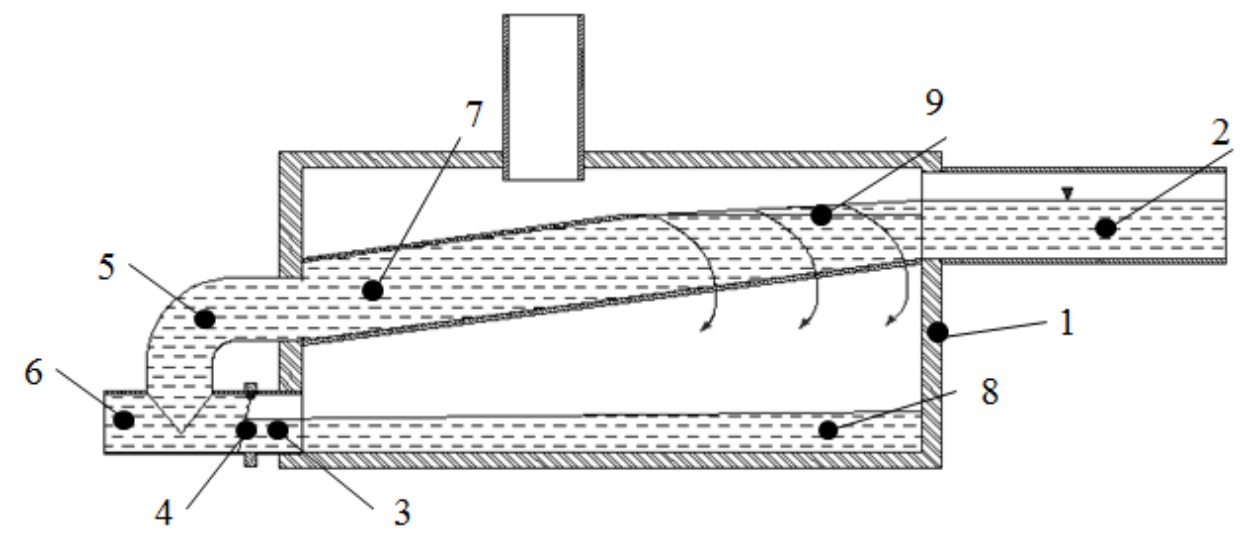

Rys. 6. Faza III funkcjonowania zbiornika

Fig. 6. Phase III of functioning of underground tank

- Warunki brzegowe w zakresie napełnienia: $h_{0.3}>h_{0.2}, h_{2.3}>h_{2.2}$, $h_{3.3}>0$.

- Warunki brzegowe ze względu na przepływy: $Q_{d o p .3}>Q_{o d p .2}, Q_{d o p .3}>Q_{d o p .2}$, $Q_{o d p .3}>Q_{o d p .2}, Q_{p .3}>Q_{p .2}, Q_{z b 1.3}>0, Q_{z b 1.3}=\left(Q_{d o p .3}-Q_{p .3}\right), Q_{z b 2.3}=0$.

\section{Faza IV}

W fazie IV następuje całkowite wykorzystanie przestrzeni akumulacyjnej zbiornika (rys. 7). Ścieki dopływające kanałem (2) są odprowadzane ze zbiornika kanałem wiodącym (5), a nadmiar ścieków przelewa się przez krawędzie przelewowe (9), aż do momentu osiągnięcia maksymalnego poziomu zwierciadła ścieków w przestrzeni akumulacyjnej (8).

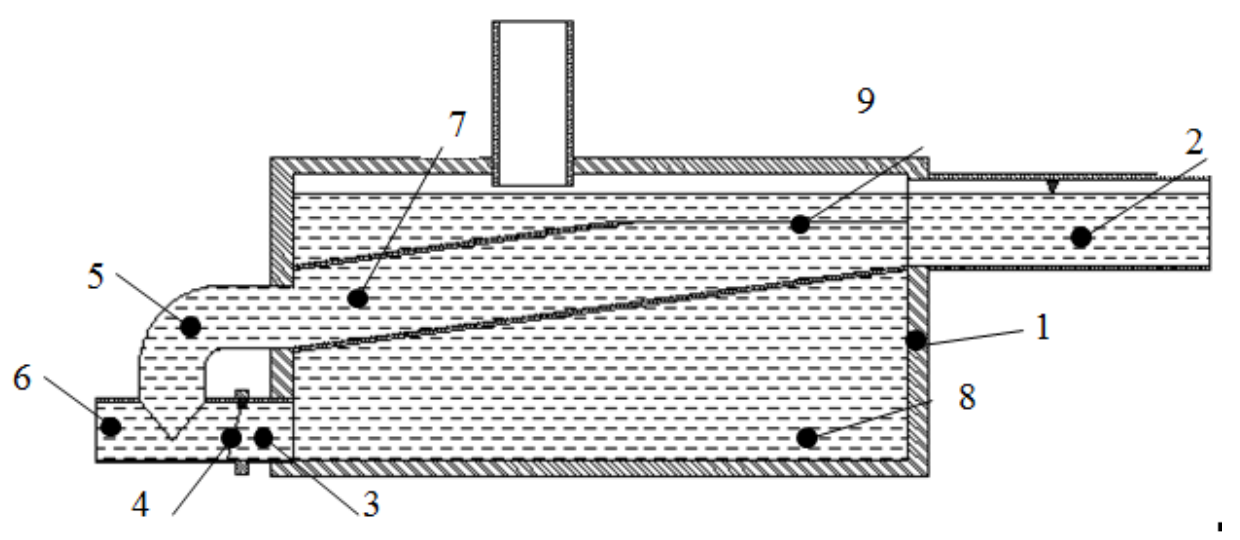

Rys. 7. Faza IV funkcjonowania zbiornika

Fig. 7 Phase IV of functioning of underground tank 
- Warunki brzegowe w zakresie napełnienia: $h_{0.4}>h_{0.3}, h_{2.4}>h_{2.3}, h_{3.4}>h_{3.3}$.

- Warunki brzegowe ze względu na przepływy: $Q_{d o p .4}>Q_{o d p .4}$, $Q_{d o p .4}>Q_{d o p .3}, Q_{o d p .4}=Q_{o d p .3}, Q_{p .4}>Q_{p .3}, Q_{z b 1.4}>Q_{z b 1.3}, Q_{z b 2.3}=0$.

\section{Faza V}

Proces opróżniania komory akumulacyjnej zbiornika przedstawiono na rysunku 8. W tej fazie dopływ ścieków do zbiornika zanika, a zwierciadło ścieków w kanale przelewowym (7) i przestrzeni akumulującej (8) osiągają zbliżony poziom. W tym czasie rozpoczyna się proces opróżnienia zbiornika, a wyrównanie ciśnienia hydrostatycznego pomiędzy ściekami w kanale przelewowym (7) i komorą akumulacyjną (8) warunkuje częściowe otwarcie zaworu zwrotnego (4).

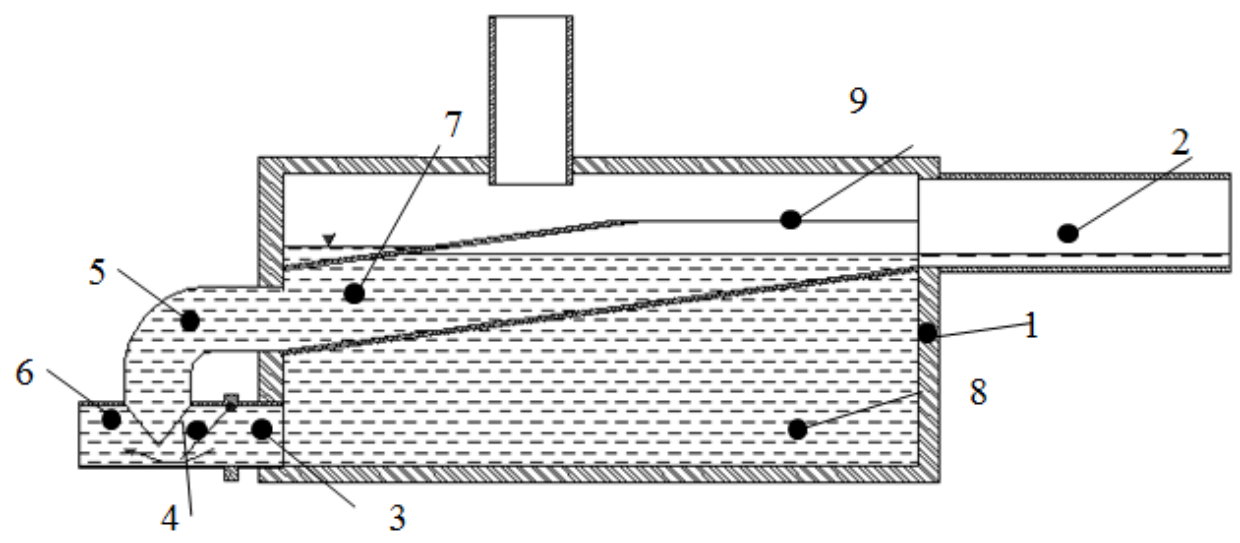

Rys. 8. Faza V funkcjonowania zbiornika

Fig. 8. Phase $\mathrm{V}$ of functioning of underground tank

- Warunki brzegowe $\mathrm{w}$ zakresie napełnienia: $h_{0.5}<h_{0.4}, \quad h_{2.5}<h_{2.4}$, $h_{3.5}<h_{3.4}$.

- Warunki brzegowe ze względu na przepływy: $Q_{\text {dop.5 }}<Q_{\text {odp.5. }}$, $Q_{d o p .5}<Q_{d o p .4}, Q_{o d p .5}=Q_{o d p .4}, Q_{p .5}<Q_{p .4}, Q_{z b 1.5}<Q_{z b 1.4}, Q_{z b 2.5}>0$.

\section{Faza VI}

W fazie VI następuje całkowite opróżnienie kanału przelewowego (7), co zaprezentowano na rysunku 9. W konsekwencji czego odprowadzenie ścieków do systemu kanalizacyjnego położonego poniżej zbiornika retencyjnego następuje jedynie poprzez kanał odpływowy (3), otwarty zawór klapowy (4) i kanał odpływowy (6). 


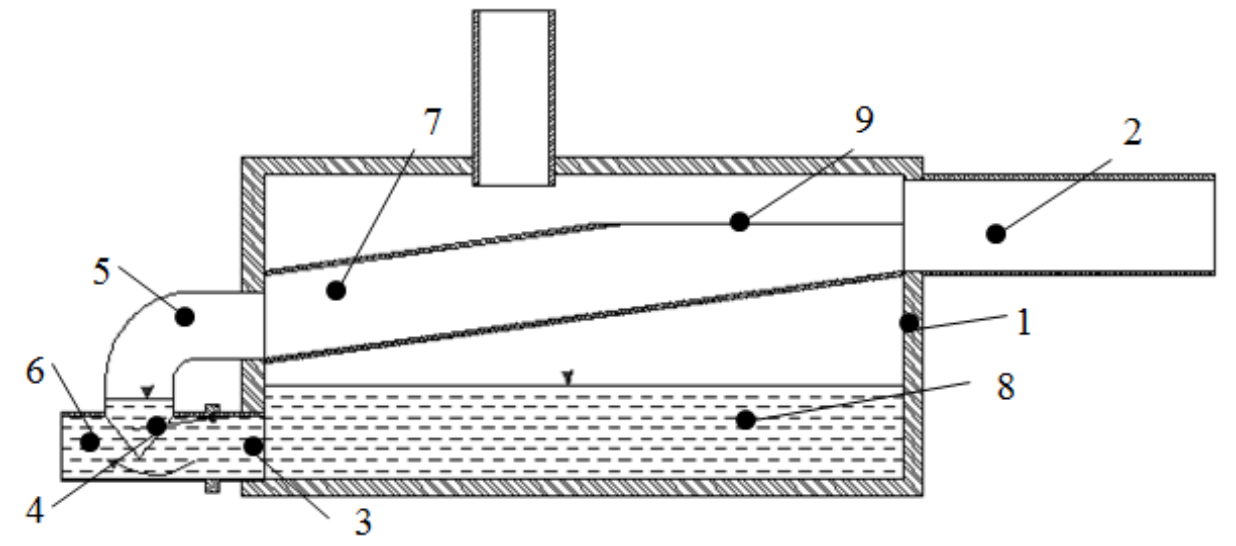

Rys. 9. Faza VI funkcjonowania zbiornika

Fig. 9. Phase VI of functioning of underground tank

- Warunki brzegowe $\mathrm{w}$ zakresie napełnienia: $h_{0.6}<h_{0.5}, h_{2.6}<h_{2.5}$, $h_{3.6}<h_{3.5}$.

- Warunki brzegowe ze względu na przepływy: $Q_{\text {dop.6 }}<Q_{o d p .6}$, $Q_{d o p .6}<Q_{d o p .5}, Q_{o d p .6}, Q_{p .6}=0, Q_{z b 1.6}=0, Q_{z b 2.6}>0$.

\section{Faza VII}

Ostania faza funkcjonowania obiektu (rys. 10) obrazuje jego stan po ustaniu opadu i zakończeniu dopływu ścieków do zbiornika kanałem (2). W tej fazie komora zbiornika (1) i kanał transportujący (7) są puste, a zawór zwrotny (4) zamknięty.

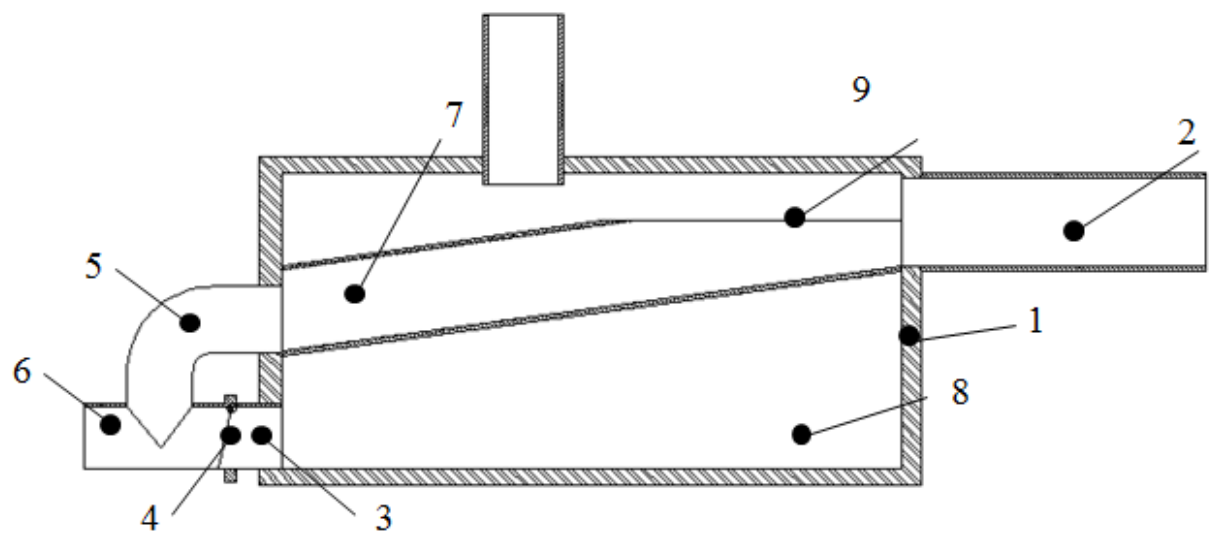

Rys. 10. Faza VII funkcjonowania zbiornika

Fig. 10. Phase VII of functioning of underground tank 
- Warunki brzegowe w zakresie napełnienia: $h_{0.7}=0, h_{2.7}=0, h_{3.7}=0$.

- Warunki brzegowe ze względu na przepływy: $Q_{d o p .7}=0, Q_{o d p .7}=0, Q_{p .7}=0$, $Q_{z b 1.7}=0, Q_{z b 2.7}=0$.

\section{Podsumowanie}

Opracowany model hydrauliczny zbiornika retencyjnego zawierający instalację minimalizującą jego niezbędną pojemność retencyjną pozwala na zwiększenie efektywności hydraulicznej obiektu przy zapewnieniu tych samych standardów odwodnienia i poziomu bezpieczeństwa systemu kanalizacyjnego.

Wykonana analiza pozwoliła stwierdzić, że w zbiorniku zawierającym rozwiązanie pn. Instalacja zbiorników retencyjnych w początkowych fazach II i III funkcjonowania nie występuje przerwanie strugi cieczy pomiędzy kanałem dopływowym i odpływowym. Pozwala to na zrównanie się wartości strumieni objętości ścieków dopływających i odpływających ze zbiornika już w pierwszych fazach jego funkcjonowania i w efekcie pełne wykorzystanie zdolności hydraulicznych kanału odpływowego.

Dodatkowo, wyniki analizy pozwalają stwierdzić, że opisane rozwiązanie uniezależnia wartość odpływu ścieków ze zbiornika od maksymalnego projektowego napełnienia ścieków w zbiorniku, a zatem jest szczególnie zalecane dla rozwiązań obiektów retencyjnych charakteryzujących się małym napełnieniem.

\section{Literatura}

[1] Brombach H.: Sewerage system and stormwater tanks as reflected in statistics, KA-Wasserwirtschaft, Abwasser, Abfall, no 4, 2002, pp. 33-40.

[2] Calabro P.S., Viviani G.: Simulation of the operation of detention tanks, 2006.

[3] Nicholas D.I.: On-site stormwater detention: improved implementation techniques for runoff quantity and quality management in Sydney, Water Science and Technology, vol. 32, 1995, pp. 85-91.

[4] Dziopak J., Starzec M.: Wpływ kierunku i prędkości przemieszczania się opadu deszczu na maksymalne szczytowe przepływy ścieków w sieci kanalizacyjnej, Czasopismo Inżynierii Lądowej, Środowiska i Architektury JCEEA, z. 61 (3/I), 2014, s. 63-81.

[5] Słyś D.: Zrównoważone systemy odwodnienia miast, Dolnośląskie Wydawnictwo Edukacyjne, Wrocław 2014.

[6] Zawilski M., Sakson G.: Efekt zastosowanie obiektów retencji na rzeczywistej zlewni miejskiej kanalizacji ogólnospławnej, Gaz, Woda i Technika Sanitarna, nr 2, 2007, s. 10.

[7] Stec A., Słyś D.: Optymization of the hydraulic system of the storage reseervoir hydraulically unloading the sewage network, Ecological Chemistry and Engineering S, no. 21(2), 2014, pp. 215-228.

[8] Dziopak J.: Modelowanie wielokomorowych zbiorników retencyjnych w kanalizacji, Oficyna Wydawnicza Politechniki Rzeszowskiej, Rzeszów 2004. 
[9] Stec A.: Optymalizacja innowacyjnych zbiorników w kanalizacji ogólnospławnej, Akademia Górniczo-Hutnicza w Krakowie, Wydział Geodezji Górniczej i Inżynierii Środowiska, rozprawa doktorska, promotor Słyś D., Kraków 2013.

[10] Czarniecki D., Słyś D.: Analiza techniczna i finansowa wariantów ogrzewania wody z wykorzystaniem pomp ciepła współpracujących z systemami rozsączania wody deszczowej w produkcji roślinnej, Czasopismo Inżynierii Lądowej, Środowiska i Architektury JCEEA, z. 61 (3/I), 2014, s. 33-51.

[11] Kordana S., Słyś D.: Analiza kosztów cyklu życia skrzynek rozsączających, Czasopismo Inżynierii Lądowej, Środowiska i Architektury JCEEA, z. 61 (3/I), 2014, s. $127-139$.

[12] Pochwat K. B., Dziopak J.: Analiza hydrauliczna funkcjonowania zbiornika retencyjnego z systemem grawitacyjnego płukania, Oficyna Wydawnicza Politechniki Rzeszowskiej, z 59, nr 2, 2012, s. 91-107.

[13] Pochwat K. B., Słyś D., Dziopak J.: Analiza opadów na potrzeby wymiarowania sieci i zbiorników retencyjnych w kanalizacji, Gaz, Woda i Technika Sanitarna, nr 7, 2013, s. 269-272.

[14] Pochwat K., Słyś D., Dziopak J.: Patent nr EP 15461517.3, Installation of retention facilities., Rzeszów 2011.

\section{ANALYSIS OF HYDRAULIC FUNCTIONING OF THE STORAGE RESERVOIR CONTAINING INSTALLATION OF RETENTION FACILITIES}

\section{S u m m a r y}

The publication describes an innovative solution called installation of retention facilities that can be used to improve the hydraulic parameters of any retention facilities. The study contains the results of analyzes of the hydraulic functioning of the one-chamber underground tank for stormwater which has innovative solution that allows to maximize the cubature efficiency of any retention facilities. Particular attention was paid for the hydraulic conditions in terms of sewage filling of the tank, primarily the leading channel and the accumulation chamber. The study was based on the analysis of various phases of the functioning of the underground tank containing the installations. The study was conducted in phases, during the rainfall, and the start of the inflow sewage into the tank, to completion of rainfall and complete emptying of the underground tank.

Keywords: storage reservoirs, innovation, volume efficacy, sewerage systems, drainage system, storm water drainage combined sewage system, hydraulic model, retention facilities

DOI:10.7862/rb.2016.171

Przestano do redakcji: 01.05.2016 r

Przyjęto do druku: 28.06.2016 r. 